В.І.Лучицька, аспірантка Інституту філософії імені Г.С. Сковороди НАН України

\title{
«ДРАМА» ЛЮДСЬКОЇ ОСОБИСТОСТІ У ФІЛОСОФІЇ Ю.ТІШНЕРА
}

Проблеми людини, які піднімаються у філософії Тішнера є актуальними і на сьогодні, про що свідчать багато зроблених досліджень. Можна відзначити праці таких науковців як В.Бачинський, В.Балус, В.Боновіч, В.Божеєвич, С.Шарий, Б.Троха та ін. У своїх наукових працях вони найчастіше зосереджуються на представленні філософії драми Тішнера, аксіологічних та етичних поглядах, його концепції людини, зокрема діалогічний вимір. У цій статті буде розглянуто його погляди на особу людини, іï формування, внутрішній досвід, драматичний аспект існування, а також діалогічний вимір. Тематика особи не $\epsilon$ новою у феноменології. Слід відзначити Е.Штайн, яка розглядала особу з онтологічної точки зору. Свої роздуми вона починала 3 представлення тілесності особи, і поступово доходила до глиби людини - iї внутрішнього світу: переживань, цінностей досвідчень. Важливу роль у розумінні особи відігравала діалогічність. У філософських поглядах Тішнера також можна побачити подібні підходи у розумінні особи, але він більш зосередився на внутрішності людини, іiі драмі.

Беручи під увагу те, що Тішнер використовує у своїх працях багато цитувань відомих філософів, можна припустити, що вони мали великий вплив на формування його поглядів. Зокрема, Тішнер у Гуссерля цінував найбільше випрацювану методику досвідчення предметів, яка може бути використана для відкриття прихованої у глибині істоту у найрізноманітніших сферах дійсності. Тішнер у своїх аксіологічних роздумах часто сягав до доробку М.Шелера, зокрема його теорії цінностей. Великий вплив на Тішнера мала філософія Гайдегера. Тішнер був одним 3 перших популяризаторів думки Гайдегера в Польщі. Він зробив переклад деяких творів. Свою філософію цінностей творив у полеміці 3 концепцією Гайдегера. Гайдегерівська ідея застосування метафізики у філософії людини була завжди близькою для Тішнера. 
Особливе місце у філософії Юзефа Тішнера займали роздуми про людину. Людина завжди була присутня у його текстах, як філософських, так і публіцистичних. На своїх заняттях, в розмовах Тішнер часто повторював, що головне питання філософії звучить так: ким є людина?

Внаслідок здійснених пошуків, у напрямку загального окреслення його філософії, можна ствердити, що він займався філософією драми. Фундаментальне ж питання філософії драми за словами Тішнера звучить так: «яка $€$ і як мусить бути побудована людина, щоби могла брати участь у драмі?» $[2,11]$. Значну увагу у своїх філософських роздумах Тішнер присвячує філософії драми, яка, на його думку: «це передусім філософія людини, яка ставить у центрі своїх роздумів людину, яка живе у визначеному просторі і конкретному історичному часі, людину, яку зустрічаємо на щодень, яка має свої обов'язки, турбується про своїх близьких, має конкретну працю, зіштовхується 3 існуванням добра і зла, стоїть перед проблемою смерті, надії» [5, 55].

Ким є особа у розумінні Тішнера? Він починає розгляд особи «як монаду без вікон» - це означає стан особи, яка досвідчує відокремленість, свою іншість, а також відчуває себе зраненою покинутою ближніми. Ця ситуація є нібито приреченістю на самотність. Поняття монади він запозичив у Лейбніца. «Монада без вікон» - це стан особи, яка закривається на існуючий світ, на зустріч з іншою особою. Вона зосереджується на своїй драмі, трагедії, болю. Але в один момент з'являється хтось біля неї. І лунає від іншої особи питання на яке слід відповісти. Можна відповісти правду, збрехати, змовчати. I саме тоді, коли людина вирішує відповідати їй чи ні, вона починає досвідчувати драму зустрічі, оскільки вона не знає що ця зустріч для неї принесе ( біль, смуток, радість, страждання, любов), чим це все закінчиться. Натомість ця зустріч передбачає пізнання іншої особи, а саме іiі болі, страждань, переживань, трагедій. I вразі, коли людина наважується на зустріч, на відповідь вона розкривається, починає бачити іншу людину, яка є відмінною і водночас схожою. Отже, відкритість - це момент радикального відкриття на інших осіб (можна прослідкувати вплив філософії Левінаса). У цій відкритості особа нібито втрачає себе, свою сутність, постає перед проблемою відданості чи жертвування себе за інших. Особа стає «буттям для іншого» $[5,55]$. Слід підкреслити, що завдяки діалогу людина може зустрітися 3 іншою людиною обличчя в обличчя, пізнати правду, добро і зло, досвідчити драму і страждання, біль i 
неспокій, тобто вийти з власного світу і відкритися на інших, на світ.

У філософії драми Тішнер прагне показати винятковість і неповторність людської екзистенції, роздвоєною між нігілізмом і вірою, розпачем і надією. У рамках цих роздумів з'являються питання про найглибший сенс людської екзистенції, питання про сенс страждання, сенс праці, сенс смерті, сенс добра.

Людська особа для Ю.Тішнера є особою драматичною - осередком індивідуальних цінностей, властивих характеристик, здібностей, умінь. Людська особа стає предметом драми через свою тілесність. I це означає, що не тільки вона сама, але також інші постають перед нею у тілі і проявляють свою сутність через тіло. Постає питання, що слід розуміти під поняттям тілесність, тіло? Тішнер пропонує розглянути насамперед два підходи (з точки зору платонівського дуалізму та 3 огляду на концепцію Гайдегера, який говорить: «субстанцією людини не $є$ дух як синтез душі і тіла, лише екзистенція» $[1,167])$ розуміння тіла і його ролі в людській особистості. Зосередьмося на разі як інтерпретував Тішнер особу, посилаючись на платонівську концепцію. Він зазначає, що Платон представляє тіло, яке є «в'язницею» для душі. Маємо дві самостійні «субстанції» і одна 3 яких $\epsilon$ «в'язницею» для іншої. Тут можна побачити конфліктну ситуацію людини з власним тілом, у певному ж сенсі з самим собою. Конфлікт можна розглядати 3 перспективи існування свободи, оскільки в'язниця є станом позбавлення свободи. На кінець можна віднайти конфлікт у тому, що тіло обмежує і ставить границі для вираження внутрішнього багатства людини.

Для більш кращого розуміння існування особи Тішнер приводить думку томістів, які ж натомість, ідучи за Аристотелем, не говорять про дві «субстанції», лише сягають до поняття форми субстанціальної і матерії. Душа є «субстанціальною формою», тіло «матерією» цієї форми. У цьому випадку не душа «ув'язнює» тіло, лише тіло потребує визволення. Тішнер зауважує, що у Платона боротьба точиться між душею і тілом починаючи з душі, яка мріє про волю; в Аристотеля боротьба починається від тіла, яке не зносить накиненого на нього ярма [4, 82].

Він проаналізувавши ці концепції стверджує, що існує конфлікт: чи то тіла 3 душею, чи то душі $з$ тілом. Як кожен конфлікт, так і цей закінчиться перемогою однієї чи іншої сторони, одного разу душі, а іншого - тіла. Тіло, яке побороло душу, поборює також себе саме, перетворюючись на звичайну «матерію» (Körper). I душа, яка поборює 
тіло, перестає бути душею, а стає «духом», який не відомо, що робить на цьому світі $[4,82]$.

Тішнер звертається до роздумів Мартіна Гайдегера, який розв'язує конфлікт між душею і тілом через впровадження нового поняття «буття людського». Людина у філософії Гайдегера являється істотою, яка бере участь у драмі «правди буття». Він називає іï Dasein. Людині, яка розуміється як Dasein «у іiі бутті ідеться про власне буття». Будучи екзистенцією Dasein «виходить з себе» до чогось, що як вважає - «насправді є» поза ним і у світлі того «насправді», повернувшись до себе, «розуміє» себе як буття. Dasein завжди і в скрізь «до уявляє себе» як буття у світлі того, що « видається йому», що насправді є. Приймаючи загальні ідеї правди буття, отримуємо погляд на себе як того, який «є поза душею і тілом» - як самого Dasein. На цьому рівні з тілесності залишається тільки чиста respective $[4,83]$.

Філософія драми спрямовує нас на рефлексію над тілом. Велику увагу Тішнер приділяє присутності іншого тіла. Він говорить, що свідомість власного тіла - зокрема: власної тілесності розглядається за посередництвом інших тіл. Правдоподібно основні конфлікти, зокрема конфлікт між тілом і духом, несе на собі відбиток тілесності іншого. Тілесність, входячи в драму, входить у цілий іiі горизонт, який $є$ горизонтом добра і зла, правди і неправди, краси і не краси.

На думку філософа:»дороговказом до розуміння тілесності може бути «пожадання». Він пропонує на початку досліджень прийняти те, що тіло є «місцем пожадань» $[4,85]$. «Пожадання» проявляється таким чином, що виражається в тілі і через тіло.

Тішнер стверджує, що пожадання народжуються десь у глибинах тілесності і виявляються на зовні як голод, прагнення, сон. Пожадання складаються 3 двох елементів: 3 досвіду і значення. Воно «означає» те, що «означає» експресія: сміх «означає» радість, плач «означає» смуток. Подібно означає відчуття голоду, прагнення, еротизму. Пожадання призначене для розуміння; розпізнати пожадання це означає його зрозуміти, а зрозуміти пожадання це проникнути на різні пізнавальні рівні, з яких воно складається. [4, 86].

Зрозуміти таємницю тіла, згідно з Тішнером, можна, розглянувши аспект часу тіла. Час не $\epsilon$ зовнішньою реальністю відносно тіла. Реалізується у тілі і залишає у ньому слід своєї присутності. Час тілесний починається 3 моменту зачаття, а закінчується моментом смерті. Між народженням і смертю людина проходить через дитинство, 
молодість, дозрілість, старість.

Згідно з Тішнером, кожен період життя пропонує людині сукупність певних цінностей «для переживання» і відкидання. Ці цінності $\epsilon$ типовими для конкретних періодів життя людини. Перший період час «забави», характеризує дитинство людини. Із забавою поєднується гра, яка окреслює передусім час молодості. Молодість проминає, коли надходить час поваги і відповідальності, пов'язаний зазвичай iз створенням родини. I у кінці старість, у якій дає про себе знати змучене тіло, з його глибини проглядається перспектива кінця. [4, 121].

На думку Тішнера, час тіла не $\epsilon$ часом математичним, не можна прослідкувати, коли закінчується один період часу життя і починається інший. Слід зауважити, що драма тілесності не є драмою тіла самотнього, відокремленого від інших істот, передусім людини. Тіло живе біля тіла і зустрічається з іншим, бавиться з ним, грається, любить, розмножується і народжує, помирає. [4, 122].

Тішнер, аналізуючи час тіла, говорить про властиві характеристики для кожного періоду життя людської особистості. Наприклад, період дитинства він розглядає по аналогії до забави, а молодість до гри. Чим же ж являється забава та гра і яка між ними різниця?

Тішнер говорить, що різниця між забавою і грою полягає у наявності чи відсутності правил. Забава протікає спонтанно, сама по собі, без накинутих згори правил; гра ж складається з певної послідовність дій, підпорядкованих зовнішнім «правилам гри». Основою забави $\epsilon$ чиста фантазія, а основою гри є світ докладно упорядкованих сенсів, значень і цінностей. Гра є характерною для молодості, хоча це не означає, що вимір забави зникає, коли проминає дитинство. Забава є експресією чистої радості життя. Радість виражається сміхом, танцем, підстрибуванням до гори - нібито у людині існують крила. Забава не потребує свідків для свого існування, що однак не означає, що хоче перебігати на самоті. Навпаки - забава прямує до комунікації, вона хоче, щоби разом 3 нею всі бавилися. Забава створює не вимушену спільноту. Не зважаючи на те, що вимір забави триває у людині до кінця життя, то однак сама забава триває відносно коротко - так коротко, як людська радість.

Тішнер ставить питання: коли забава стає грою? I відповідає: тоді, коли забава починає підпорядковуватися зовнішнім правилам, які окреслюють ціль забави. Забава позбавлена цілі, на відміну від гри, яка передбачає виграш. Зовнішні правила окреслюють початок гри, іiі перебіг і кінець. Окреслюють передусім правила поведінки 
учасників гри, роблячи тим самим з людей «гравців». Не слід віднаходити у цій зміні якогось «утиску свободи». У кінці кінців ніхто не мусить приступати до гри. Можна сказати, що перехід від забави до гри означає перехід від періоду дитинства до молодості. Внаслідок гри у людині починається розвиватися почуття відповідальності. Найпершим прояв відповідальності є відповідальність за перебіг гри [4, 128].

Згідно з Тішнером, гра потребує поля або столу, м'яча для гри або карт, шахівниці тощо. Простір втрачає свій натуральний характер і набуває нового значення. На полі гри не має предметів пожадання, їхнє місце займають знаряддя гри. Нове значення предметів $є$ значенням спільним для усіх учасників гри. Хто грає, той рахується 3 програшем. Але чим $\epsilon$ програш? У світі, в якому все $\epsilon$ грою, прирівнюється до смерті. Той хто програв «виходить 3 гри» $\mathrm{i}$ не $\epsilon$ вже «гравцем». Ким $\epsilon$ ? $€$ «переможеним», чи ніким». Великий програш у великих іграх закінчується часто самогубством [4, 128].

Для більш повного розуміння гри Тішнер прибігає до думки Кіркегарда. Кіркегард найперше звертає увагу на розрізнення того, що насправді різне - жінку і чоловіка. Відмінною є гра чоловіка $\mathrm{i}$ жінки. Їхні взаємні стосунки є стосунками «омани». Омана пригадує відношення художника до твору мистецтва. Чоловік у певному сенсі «створює» жінку, але і жінка - як його витвір мистецтва «створює» художника. Жінка «віддається» чоловіку з переконанням, що іiі віддання $є$ рівнозначне 3 володінням. У годину щастя можуть сказати до себе: «мій-моя». Дякуючи один одному є самими собою - жінкою та чоловіком; доповнюють навзаєм свідомість власної ідентичності $[4,129]$.

Кіркегард описує всі етапи і аспекти гри омани. Виявляє переміни цінностей речей. Не залишає він поза увагою жодної зворушливості, жодного болю вчиненого і зазнаного в ім'я великої перемоги. Омана реалізується у світлі досвіду «естетичного», який має подвійний сенс: він виникає у стихії прекрасного, і по-друге походить 3 відчуття «геніальної вразливості». Кіркеггард називає це так: «геніальність відчуттів» $[4,130]$. Для того щоб побачити, чим насправді є відчуття людини, треба їх впіймати у стосунках «омани», коли $є$ цілковито охопленим іншим. Інший далі залишається «тим самим» і водночас «іншим». Чим більше його розуміє, тим більше у ньому таємниці; чим більше ним володіє, тим справніше вислизає з володіння.

Кіркегард говорить про драму, яка наступає під кінець гри, коли 
хтось програє. Там, де цінність і реальність людини заключається у грі, де ціла людина перетворюється у «гравця», програш означає для неї кінець всього, що для людини мало значення. Не було би у цьому нічого дивного, якби переможений помер. Але переможені живуть. Тільки деякі чинять самогубство. Живуть так, «якби померли». Живуть «заручниками смутку», живуть відчуваючи себе «найнещаснішими», живуть як «витинанки 3 чорного паперу», як жертви «меланхолії» [4, 134-135].

Тішнер говорить, що для розуміння сенсу гри Гайдегер впроваджує поняття автентичність, яка має окреслити сенс гри, в якій бере участь Dasein перед обличчям смерті, передусім з собою самим. Ставкою гри є «буття собою». У цьому поняттю прихована певна двозначність. Тішнер говорить, що не відомо, чи ідеться про те, щоби Dasein стало «буттям абсолютним», а зрештою нескінченним Богом, чи буттям $з$ точки зору індивідуальності і неповторності. Обидві можливості є однак рівно неможливими. Людина не є у стані стати Богом, не втрачаючи своєї людської індивідуальності. I не є також в стані стати буттям радикально індивідуальним; втративши тоді будь яку можливість порозумітися з іншими $[4,135]$.

Тішнер, підсумовуючи постулат Гайдегера, однак вбачає у ньому певний сенс. Хоча він пропонує на початку окреслити поняття автентизму, але не за допомогою категорій онтологічних. Буття основне поняття онтології - $\epsilon$ тим, чим $\epsilon$, і не має у ньому поділу на правду і фальш. Тільки буття свідоме себе може бути втіленням неправди і стати перед проблемою автентизму або його браку. Свідомість може бути свідомістю внутрішньо фальшивою - може існувати як «фальшива свідомість». Бути «втіленням неправди» це переживати цінності так, якби їх не переживали, і не переживати так, якби їх переживали. Щоби побачити цей фальш у людині слід сягнути до агатологічної і аксіологічної свідомості людини $[4,138]$.

Наступний період життя Тішнер називає періодом відповідальності. Він зазначає, що почуття повної тілесної відповідальності з'являється у житті людини відносно пізно. Важко окреслити певну дату його появи, відомо $є$ тільки те, що це явище сильно пов'язане 3 розвитком тіла. Зазвичай її появу пов'язують із здатністю укладати шлюб. Час зрілості не приходить зненацька, лише є наслідком прожитих попередніх часів, які були своєрідною підготовкою. Правила забав та ігор, які діти самі собі накидають, виявляються підготовкою до розуміння правил звичаю і засад моральності $[4,139]$. 
Тішнер говорить, що пережиття відповідальності поєднує дві крайності. 3 однієї сторони це є одне з найбільш духовних переживання, які стосуються досвіду добра і зла, свободи, провини, трансценденції. 3 другої сторони - це $є$ пережиття тілесне, яке виражається у психічній напруженості, інколи безсонням, а навіть фізичним змученням. Свідомість відповідальності походить 3 глибини особи і огортає іiі цілком. Можна сказати: особа - це повнота ii відповідальності [4, 139].

На думку Тішнера, існують деякі аспекти переживання відповідальності, зокрема ті, які пов'язані з досвідченням тілесності. 3 плином часу стає явне те, що в глибині тілесності приховується і дозріває готовність до жертви 3 тіла. Готовність до жертви виражається ще у малому віці хлопчика, наприклад, готовність до ризику у грі і чутливістю дівчинки у стосунку до ляльки чи тваринки. Незалежно від різниць у способі переживання власної статі жінку і чоловіка чекає якась жертва. Жінка, стаючи матір'ю, ризикує своїм життям. Чоловік ризикує співвідповідальністю. Людина може однак втекти від жертви. Може обгрунтовувати свій бунт проти жертви, наприклад, наявністю страху. Може це бути страх перед смертю, може бути також страх перед відповідальністю. Існує великий перелік страхів в психоаналізі. Страхи тілесні у значній мірі є страхами перед потребою жертви і як такі спрямовані до затримання часу тіла під час гри чи забави $[4,140]$.

Тішнер стверджує, що для того, щоб існувала жертва має бути вибір. Вибір мусить бути радикальним. Вибір цей не стосується тієї чи іншої життєвої цінності, лише життя в цілому. Не є жертвою вибір між цінностями того самого роду: хто бере до вуст ліки, не звертаючи уваги на те, що є вони є гіркими, не здійснює жодної жертви, подібно як той, хто замість вивчати історію мистецтва, вибирає курс географії. Або наприклад спортсмен, який багато тренується, аби взяти участь в олімпіаді, не чинить жертви, хоча безсумнівно присвячується цій справі. Посвячення тим відрізняється від жертви - радикальної жертви - що не є тільки менш радикальне, але також, що в його випадку можна розраховувати на нагороду, натомість у випадку жертви зникає думка про нагороду, а на передній план виступає свідчення - свідчення правди, свободи. На яку нагороду може розраховувати солдат, який помирає за Батьківщину? Людина дає свідчення, щоби показати, як є чи як повинно бути. Тут не ідеться про нагороду. У жертві виходить на 
яв особливий зв'язок людини з людиною - того хто жертвує собою, і того, за кого робиться жертва - зв'язок «заступництва». Еммануель Левінас говорить про «субстанцію». Означає це: «я не тільки з тобою, але і за тебе» [4, 140-141].

Згідно з Тішнером, жертва приховує три істотні моменти: $є$ жертвою за когось, для когось, жертвою $з$ чогось. Бути жертвою означає дозволити на знищення того, що підлягає знищенню, зокрема тіла людини. Тіло є смертельне. Смерть по своїй природі $є$ кінцем життя. Як така не має сенсу. Натомість, коли вона стає жертвою набуває глибшого значення. Помираю за тебе... помираю для тебе... 3 моєї смерті постає твоє життя. Це все стосується тіла і охоплює його цілковито.

Отже, було вже з'ясовано поняття драми людської тілесності, а тепер необхідно розібратися у тому, чим $є$ драма внутрішня. Тішнер говорить, що розуміти драму це зрозуміти, що людина $\epsilon$ iстотою драматичною. Бути драматичною істотою означає: переживати даний час, маючи навколо себе інших людей і землю як сцену під ногами. Людина не була би драматичною екзистенцією, якби не три чинники: відкритість на іншу людину, відкритість на сцену драми і на плинність часу.

Тішнер зазначає, що зазвичай звертається найперше увага на розуміння часу. Драматичний час не слід розглядати 3 математичної точки зору чи природознавства (впродовж якого відбуваються процеси фізичні, хімічні, переміни мікро і макрокосмосу). Він не $\epsilon$ часом природи, у якому протікає життя рослин і звірів від народження до смерті. I не $\epsilon$ часом внутрішньої свідомості у сенсі, який надав цьому поняттю Едмунд Гуссерль. Отже, це $\epsilon$ час, який спливає серед нас, учасників однієї і тієї ж драми. Драматичний час поєднує мене з тобою, а тебе зі мною і водночас пов'язує нас зі сценою, на якій відбувається драма. Цей час не існує у мені ані в тобі, лише $є$ між нами. Має він властиву тільки йому логіку, яка керує його плином і невідворотністю. Не можна зупинити час, який проходить між нами. Плинність нашого часу є якби субстанцією драми [3, 312].

Тішнер зауважує, що під нашими ногами є наш світ - сцена драми. Ми ходимо по ній, бачимо іiі, чуємо і також дотикаємо іiї руками. Уявлення про сцену можуть бути різними; різними можуть бути представлення і теоретичні концепції; однак єдине, що є стале це сцена. Наприклад, для Аристотеля сцена - повнота самоіснуючих речей - субстанцій, для Берклі - спільний витвір уяви людей - сон. 
Але для людей задіяних у сцені життєвої драми вона є передусім місцем зустрічей і розлучень, є простором свободи, у якому людина шукає собі дім, хліб, Бога, і у якій віднаходить цвинтар. Людина досвідчує сцену, упредметнюючи іï, замінюючи іiі на простір сповнений «предметами», з яких потім утворює різноманітні сукупності, які їй слугують. Об'єктивізація є можлива завдяки інтенціональним актам. Тому відношення людини до сцени називає відношенням інтенціональної об'єктивізації [3, 312].

Він говорить, що навколо мене і біля мене знаходяться люди, особливо ті, які є учасниками тієї самої драми, у якій і я беру участь. Я їх не бачу, не чую, не дотикаю і взагалі не помічаю. Те, що помічаю $є$ тільки зовнішнім, а не людиною як людиною, іншим як іншим. Інша людина може появитися тільки тоді, коли стане переді мною як учасник моєї драми. Участь у драмі не може супроводжуватися ані слуханням, ані баченням - вимагає вона цілковито іншого відкриття ніж відкриття властивого інтенціональній свідомості.

На думку Тішнера, відкритість на іншого має характер діалогічний. Відрізняється вона від інтенціонального відкриття. Завдяки інтенціональній відкритості постає перед нами світ предметів, завдяки діалогічній відкритості постаєш переді мною Ти.

У роздумах Тішнера людина являється драматичною істотою. Природою драми є драматичний час також дві відкритості - інтенціональна відкритість на сцену і діалогічна відкритість на іншу людину. Бути драматичною істотою, на його думку, означає: існувати в окресленому часі і в окреслений спосіб відкриватись на інших і на світ - сцену [3,314]. Людина бере участь у драмі в інший спосіб ніж речі, які знаходяться на сцені. $Є$ драматичною істотою в іншому сенсі, ніж є жінкою чи чоловіком, дитиною. Беручи участь в якійсь драмі, людина знає більш або менш ясно, що - говорячи метафорично - в іiі руках є iii згуба чи порятунок. Бути драматичною істотою це вірити - правдиво чи неправдиво - що згуба або порятунок $є$ в руках людини. Людина може не знати в чому заключається іiі згуба і в чому іiі порятунок, принаймні може мати свідомість, що про щось таке власне ідеться у житті. Будучи переконаним, що згуба і порятунок в її руках, людина керує своїм життям відповідно до цього переконання.

Для кращого розуміння інтенціональної відкритості Тішнер посилається на Гуссерля. У якого інтенціональне є актами свідомості. Означає те, що вони по своїй суті спрямовані на якийсь предмет. Хто 
однак говорить про предмет, думає тим самим про суб'єкт; не може бути предмету без суб'єкта ані суб'єкта без предмету. Предмет і суб'єкт між собою міцно пов'язані на засаді протиріччя. Суб'єкт $\epsilon$ протиріччям для предмету, а предмет для суб'єкта. Не виключає це їхньої приналежності один до одного, їхньої єдності. Можна сказати, що між предметом і суб'єктом існує єдність протиріч $[3,315]$.

Гуссерль не говорить тут про відношення між цими поняттями. Відношення інтенціональне є відношенням суб'єкта свідомості до предмету свідомості. Гуссерль потім окреслить ці відношення конституюванням сенсу. 3 цього випливає, що акти свідомості породжують (генерують) сенс - зокрема сенс предметний, як і суб'єктивний. Предмет, про який говорить Гуссерль, є самим сенсом предметним (сенсом буття предметом), тобто предметом у значенні кореляту суб'єктивного акту свідомості. Подібно суб'єкт, то чистий суб'єкт свідомості.

Тішнер зазначає, що ця ідея інтенціональності може послужити для кращого вияснення сцени, яка розуміється як світ, на якому реалізується людська драма. Слово «на»є тут особливо важливе. Ми є на світі як на сцені. Наш стосунок до сцени може впродовж тривання драми змінюватися і може бути різним у залежності від роду предметів, які знаходяться на сцені. Але те, що є фундаментальне не підлягає зміні - це відкрита можливість упредметнювання. Упредметнювання може здійснюватися, частина за частиною, цілий світ. Необхідно добре розуміти значення цього поняття. Говорячи, що якась річ підлягає «упредметнюванню», не стверджуємо, що дістала щось, чого раніше не мала. Стверджуємо скоріше, що відкрила те, що від самого початку було іiї основою $[3,320]$.

Тішнер наголошує, що сцена не може бути виключно для мене, вона мусить бути також сценою для інших. I в цьому напрямку дає про себе знати фундаментальна свідомість присутності іншої людини. Інша людина опиняється близькою: ближче ніж сцена. $€$ присутня, потім з'являється на сцені як та, яку зустрічаю. Є присутня як укрита сила, яка домагається спільної площі, дороги, місця. Оскільки сцена має бути не тільки для мене, також для інших, мусить бути збудована з чогось, що має загальний сенс, що через усіх мусить бути визнана існуючою насправді. Якби не було сцени, не було би «де» місця зустрічі.

Отже, доходимо висновку, що важливу роль у філософії драми Тішнер відводить діалогічній відкритості. Діалогічна відкритість на іншу людину: на «ти», на «він і вона», на «ми, ви і вони». У ній 
інша людина є присутня для мене, а для іншого. Інша людина є присутня біля мене через те, що треба, щоби для неї зробив; і я є при ній присутньою через те, що треба, аби вчинив для мене. Зв'язок, який народжується між нами, є зв'язком зобов'язання.

Зобов'язання виникає під час зустрічі. Для того, щоб зустріч людей відбулася потрібно мати їм подібні зацікавлення, подібні смаки, подібне минуле, подібні надії. Особа, вступаючи у діалог 3 іншою особою, приносить 3 собою певну ієрархію цінностей, інша ж особа також має свою ієрархію. Діалог буде тільки тоді плідним, коли наші ієрархії будуть схожими або коли будуть здатними уподібнитися одна до одної.

Розглянувши філософські погляди Ю.Тішнера можна побачити чітко, що він використовує феноменологічну методику, тобто розкриває суть особи найперше 3 - зовні - тілесність, а потім внутрішнє переживання « драми особи». Пунктом виходу для розуміння тілесності є її пожадання з одного боку, а з іншого - час тіла, тобто конкретні періоди життя людини, починаючи з дитинства і до кінця. Ці періоди мають свої характерні риси та назви, наприклад час забави, гри, відповідальності. Внутрішня суть особи заключається в iii драматичності. Драма розкриває стосунок людини до сцени, до іншої людини; можна говорити також про драматичний час. Велику увагу Тішнер приділяє зустрічі з іншою собою, говорячи про діалогічність. Можна погодитися з його думками, що таємниця людини розкривається в момент зустрічі з іншою людиною.

\section{ЛIТЕРАТУРА}

1. Heidegger M. Bycie i czas. Tłum. B. Baran. - Warsawa 1994, s.167.

2. Tischner J. Filozofia człowieka dla duszpasterzy i artystów. - Kraków, 1991, S.11.

3. Tischner J. O człowieku. Wybór pism filozoficznych. - Wrocław: Zakład Narodowy im. Ossolińskich, 2013. - $725 \mathrm{~s}$.

4. Tischner J. Spór o istnienie człowieka. - Kraków: Znak, 2011. - 419 s.

5. Wilczek A. W poszukiwaniu prawdy o człowieku spór Tischnera $\mathrm{z}$ tomizmem // Czasopismo Filozoficzne. - 2009. - nr 4/5. S. 52-72. 
Лучицька В.І. «Драма» людської особистості у філософї Ю.Тішнера.

Особливе місце у філософії Ю.Тішнера займали роздуми про людину. Тішнерівська філософія людини, яка являє собою постійний пошук правди про людину, пройшла кілька фаз. Перший період характеризувався великим впливом феноменології та теорії цінностей. У другому періоді, який знаходився під впливом філософії діалогу, Тішнер ставив на перше місце драму людина розглядалася передусім як істота драматична, яка екзистує на горизонті добра і зла. Важливе місце у його філософії займає аксіологія і агатологія.

Істота драми, за словами філософа: «Беручи участь у якійсь драмі, людина більш менш ясно знає, що - говорячи метафорично - у іiі руках є іiї загибель чи спасіння. Бути істотою драматичною, означає вірити - правдиво чи неправдиво - що загибель чи спасіння $є$ в руках людини».

Ключові слова: Філософія людини, особа, людське тіло, час тіла, драма, філософія, драматична істота, діалогічність.

Лучищька В. І. «Драма» человеческой личности в философии Ю Тишнера.

Особенное место в философии Ю.Тішнера занимали размышления о человеке. Тишнеровськая философия человека, которая являет собой постоянный поиск правды о человеке, прошла несколько фаз. Первый период характеризовался большим влиянием феноменологии и теории ценностей. Во втором периоде, который находился под воздействием философии диалога, Тішнер ставил на первое место драму - человек рассматривался прежде всего как существо драматическое, какое екзистирует на горизонте добра и зла. Важное место в его философии занимает аксиология и агатология. Существо драмы, по словам философа: «Участвуя в какой-то драме, человек более или менее ясно знает, что - говоря метафорически - в его руках есть его гибель или спасение. Быть существом драматическим, значит верить правдиво или неправдиво - что гибель или спасение есть в руках человека».

Ключевые слова: Философия человека, личность, человеческое тело, время тела, драма, философия, драматическое существо, диалогичность.

Luchytska V. «Drama» of human personality in J.Tishner 's philosophy.

Thinkings about the human have a special position in J. Tishner's philosophy. Tishner's philosophy of human, which is a permanent search for the truth about man, has gone through several periods. The first period was characterized by a major influence of phenomenology and theory of values. In the second period, which was influenced by the philosophy of dialogue, drama is on the top - a man was seen primarily as being dramatic, that blows hot and cold between good and evil. Axiology and agatology take an important place in his philosophy.

If we are speaking metaphorically, the essence of drama according to the philosopher: «Taking part in some drama, person more or less definitely knows that in his hands is his destruction or salvation. Being a creature dramatic means to believe - honestly or dishonestly - that death or saving is hold by a man».

Key words: Philosophy of man, the person, the human body, a body, drama, philosophy, drama being dialogic. 